\title{
THE FOUNDATIONAL DECADES OF MALAYSIA-SOUTH KOREA ECONOMIC RELATIONS 1960-1981
}

\author{
Song Miyoung \& Sivachandralingam Sundara Raja
}

\begin{abstract}
This article examines Malaysia-South Korea economic relations during the period before Dr. Mahathir became the Malaysian Prime Minister in 1981. A great deal is known about Malaysia's relations with South Korea during Dr. Mahathir's era, especially pertaining to his Look East Policy and how it benefited both countries. However, very little is known about the development of economic relations prior to the Mahathir administration. Strong economic ties between both countries can be traced beginning from Prime Minister Tun Hussein Onn's era (1976-1981). Interestingly Koreans learnt from Malaysia's experiences in rural modernization and this later became the basis for the implementation of Saemaul Undong in the 1960s. This article traces the origins of Malaysia-Korea economic relations from the 1960s until the end of Tun Hussein Onn's era. It focuses on factors that influenced bilateral relations, reasons for establishing diplomatic ties and the role played by Tunku Abdul Rahman, Tun Razak and Tun Hussein Onn in strengthening bilateral ties.
\end{abstract}

Keywords: South Korea, economic development, Tunku Abdul Rahman, Tun Razak and Tun Hussein Onn

\section{Introduction}

This article deals with Malaysia-South Korea bilateral relations, which developed gradually over the years out of rather different historical experiences. The Federation of Malaya gained its independence on 31 August 1957. The name Malaya was re-christened to Malaysia on 16 September 1963 as a result of the union of Federation between Malaya, Singapore and the Islands of Borneo, namely North and the South Borneo, presently known as Sabah and Sarawak. However, Singapore was expelled from the Federation in 1965 and formed an independent state. 1 In comparison, in the aftermath of World War II, the Korean Peninsula was divided into Soviet and U.S. zones of occupations. A separate election which was held in the U.S. zone in 1948 led to the creation of the Republic of Korea (ROK), commonly known as South Korea. The Democratic People's Republic of Korea (DPRK), on the other hand, was established in the Soviet zone in the same year.

Geographically, Malaya and South Korea were distinctly different in that the former is located between the Indian Ocean and the Western Pacific Ocean, as well as between the Asian Continent and the Indonesian Archipelago. These made Malaya play a pivotal role in Southeast Asia and the Asia-Pacific region. It is a well-known fact that Malaya is situated on one side of the Straits of Malacca, which is arguably "one of the world's great international highways since historical times and substitutes the shortest sea journey between Southern and

1 C.M. Turnbull, A History of Modern Singapore, 1819-2005, Singapore: National University of Singapore (NUS) Press, 2009, p. 89. The separation of Singapore from Malaysia on 9 August 1965 was the result of deep political and economic differences between the ruling parties of Singapore and Malaysia, which created communal tensions that resulted in racial riots in July and September 1964. 
Eastern Asia".2 On the other hand, the geographical position of South Korea, between bordering with China and Russia to the North and the islands of Japan to the East, is considered a regional axis in understanding East Asian international relations. Thus, the country's strategic position naturally has invited the involvement of global and regional powers, namely the United States, Russia, China and Japan. Although the general features of Malaysia and South Korea are quite different, there are two significant similarities in their historical experiences, namely the experience of colonisation and the threat of communism. These contributed much in shaping and moulding their world views, thereby influencing their foreign policy and implementation of foreign relations.

The history of Malaya was largely characterized by the colonization by Europeans, particularly the British, when the English East India Company took charge of the Penang Island from Sultan Abdullah of Kedah in 1786. Britain's subsequent extension of political and economic control over the Malay states took place from the late nineteenth to the early twentieth century. During the Second World War, the Japanese also established a regime and colonized the country. On the other hand, South Korea's strategic location resulted in it being the major target of Japanese aggression in the form of economic exploitation and elimination of national awareness. 3 Japanese colonial rule in South Korea lasted for a much longer period of 35 years (from 1910-1945) as compared to only about 4 years in Malaya (1941-1945). Although South Korea somewhat underwent a period of economic growth under the Japanese, the benefits were all dedicated to the Japanese inhabitants of South Korea. Most of the South Koreans remained poor. The older generation of South Koreans, furthermore, vividly remember the time when their people were among the poorest in the world during and following the Korean War in the 1950s.

According to Dato' Santhananaban, a former Malaysian diplomatic officer, Malaysia (back then Malaya) and South Korea were labelled as 'backwaters' in the 1950s.4 Malaysia was in the state of Emergency whereas South Korea depended on external aid for development.5 However, both countries began to take steps towards economic development from the 1960s. In May 1961, Tunku Abdul Rahman announced the plan of forming Malaysia through politically merging Peninsular Malaysia with Singapore. This amalgamation was thought to have the effect of stimulating large-scale economic development through regional and intra-regional cooperation. This article traces the initial phase of economic relations between Malaysia and South Korea in the 1960s and the 1970s, as a prelude to the widely known unprecedented progress made in the 1980s.

\footnotetext{
2 M. Pathmanathan, Readings in Malaysia Foreign Policy, University of Malaya, Kuala Lumpur, 1979, p. 32.

3 Lee Kyung Chan, 'South Korea-Malaysia Relations', Master's Dissertation. Department of Southeast Asian Studies, Faculty of Arts and Social Sciences, University of Malaya, Kuala Lumpur, 1995.

4 Santhanaban began his career in 1972 as an Administrative and Diplomatic Officer at the Ministry of Foreign Affairs, Malaysia. He served in various capacities both at the Ministry of Foreign Affairs in Kuala Lumpur and at Malaysian diplomatic and consular missions abroad. He retired from diplomatic service after relinquishing his post as the Malaysian Ambassador to the Republic of Korea in July 2008.

5 M. Santhananaban. 'Malaysia's First Ambassador', in Fauziah Mohamad Taib, Eds, Number One Wisma Putra, Kuala Lumpur: Institute of Diplomacy and Foreign Affairs, 2006, p. 23.
} 


\section{The Origins of Malaysia-South Korea Economic Relations}

The year 1960 is a distinctive starting point in Malaysia-South Korea relations as both countries agreed to establish diplomatic relationship.6 Despite the great prospect for economic benefits between the two nation states, the potential did not materialize until 1975.7 This was largely due to the fact that until the mid-1970s South Korea was largely concerned with problems on the Korean Peninsula. Malaysia, on the other hand, was confronted with heightened tensions with Indonesia and Singapore's departure from the Federation. 8 Before the 1970s, the relationship between Malaya and South Korea was initiated based on their shared anti-communism ideology.9 Economic relations, therefore, did not progress beyond Malaysia being a supplier of raw materials. 10

Little is however known about Malaya's contribution to South Korea's economic growth in the $1960 \mathrm{~s}$ - a period characterized by rapid industrialization and an average of more than 8 percent Gross Domestic Product (GDP) growth per yer. South Korea's industrialization policy was based on its adoption of an outlook-looking strategy, in which Malaya played a key role. The latter supplied natural resources pertinent for South Korea's industrialization. Over the years, Malaya continued to play an important part in the economic growth of South Korea. However, the exports of Malaya were limited to raw materials, such as saw logs, crude natural rubber, tin and palm oil.11 The exports of manufactured and nonmanufactured goods were not extensive enough to strengthen the bilateral trade relations. Further, the South Korean market was heavily protected by tariff and non-tariff barriers. As South Korea suffered from an annually recurrent deficit in its balance of trade, it had very strict foreign exchange regulations. This obstructed the entry of Malayan products into Korean markets. However, since there was an immediate need for foreign exchange to finance its development plans, the government of South Korea exempted raw materials and

6 In 1965, South Korean businessmen became actively involved in the timber business in Malaysia. For instance, out of 96 South Koreans who were reportedly in Malaysia (including six embassy personnel from Singapore), 46 were engaged in logging business. Some of the South Korean companies located in Miri exported logs, extracted from Sabah to South Korea. These businesses later shifted to the peninsula while others expanded into furniture manufacturing industry (See Daljit Singh and Reza Y. Siregar, 1997).

7 D. Singh, ASEAN and Korea: Emerging Issues in Trade and Investment Relations, Singapore: Institute of Southeast Asian Studies, 1995, p. 22.

8 D. Hindley, "Indonesia's Confrontation with Malaysia: A Search for Motives", Asian Survey, Vol. 4, No. 6, 1964, pp. 904-913.

9 See L. Skvortsov, The Ideology and Tactics of Anti-Communism (Myths and Reality), Moscow: Progress Publishers, 1969. Organized anti-communism developed in reaction to the rise of communism, especially after the 1917 October Revolution in Russia. It reached global dimensions during the Cold War, when the United States and the Soviet Union engaged in an intense rivalry.

10 South Korean exports to Malaysia in 1963 amounted to USD 755000, which was a mere 0.8 percent of its total exports. They consisted of textile and agricultural and marine products. Malaysia's exports to South Korea were valued at USD 476800, mostly raw materials such as timber, rubber, coconut, and tin (D. Singh and R.Y. Siregar, ASEAN and Korea: Trends in Economic and Labour Relations, Singapore: Institute of Southeast Asian Studies, 1997, p. 57).

11 Statistics Report on Malaysia's Trade with the Republic of Korea, Department of Statistics, National Archives of Malaysia. 
capital goods that were considered essential for the national economy.12 The origins of Malaysia-South Korea relations can be more specifically analyzed within a set of economic and non-economic factors.

Malaya-South Korea relations can be traced back to 1954 when a Korean Goodwill Mission, which was part of the Southeast Asian Tour, visited the soon-to-be independent Malaya to meet local leaders.13 The first ever social interaction between representatives of both countries took place during this 1954 visit. As Malaya was considered the largest producer of tin and rubber, the main objective of the Korean mission was to understand and to educate themselves on the production of these commodities in the country.14 There was also another goodwill visit in 1961. During this visit, the Koreans praised Malaysia's rural development policy, which was seen as a crucial step in the defence of democracy against communist infiltration. Choi Duk Shin, South Korea's ambassador to Vietnam, was full of praise of Malaya's rural development plan. 15

During this time, Malaya was in a state of Emergency, as the country was involved in an internal conflict against armed communist insurgency, which originated under the British from 1948 and lasted throughout the post-independent era until 1960. Against this backdrop, in 1958, Tunku Abdul Rahman sent a proposal to President Rhee on establishing diplomatic relationship with South Korea. Sharing a similar strong stand against communism, the government of South Korea showed great interest in establishing diplomatic ties with Malaya. This was symbolized with an aide-memoire, presented to the Malayan High Commissioner in London in 1960 ("Transition to a Democracy and Transformation into an Economic Powerhouse").16 This led to the historic beginning of diplomatic relations. It formalized not only their bilateral ties but also trade relations. Tunku Abdul Rahman, the first Malaysian Prime Minister, was a key person in the establishment of bilateral relations with South Korea. Evidently, the Malayan government adopted a favourable policy towards Seoul in the 1960s. Rhee Syngman, then a diplomat representing South Korea, and Tunku Abdul Rahman succeeded in establishing diplomatic relations in February 1960. During the negotiations, Brigadier General Ibrahim of the Malaya's Army's and Jack De Silva, who was

12 S. Sukirno, "Growth and Transformation of the Malaysian Economy", 2004, www.ekonomikerakyatan.ugm.ac.id.

13 "Malaysia-Republic of Korea Diplomatic Relations 1960-2010” (unpublished manuscript), Kuala Lumpur: Arkib Negara Malaysia (Courtesy of M. Prabhakaran of the National Archives of Malaysia), p. 25. The first Korean Ambassador to Malaya in 1962 was Choi Hong-Hi, a retired army general who played a leading role in establishing Malaya's first Taekwondo Association and a year later in 1963, gave that martial art national recognition when he performed a public demonstration at the Stadium Negara in Kuala Lumpur at Tunky Abdul Rahman's the behest. The second ambassador was Choi Kyu-Hah. He served as the Korean Foreign Minister and then Prime Minister and President of Korea for a short period of time.

14 G. Govindasamy, 'Malaysia-Korea: 50 Year Relationship', in Geetha Govindasamy, Park Chang Kyoo and Tan Soo Kee, eds, Korean Affairs: A Contemporary View. Kuala Lumpur: Department of East Asian Studies, University of Malaya, 2010, p. 52.

15 "Rural Move Praised by Koreans", New Straits Times, 26 July 1961.

16 "Transition to a Democracy and Transformation into an Economic Powerhouse", www.korea.net. An aide memoire is a written summary or outline of important items of a proposed agreement or diplomatic communication. 
later appointed as the first ambassador of the Republic of Korea, played important roles in establishing the relationship. 17

\section{Malaysia's Contribution to South Korea's Rural Development Programme}

In the 1960s, there were many goodwill visits between South Koreans and Malaysians primarily to learn more about each other. The former was primarily interested to learn about Malaysia's rural development programme. On 27 October 1962, two economic delegates from South Korea visited Malaya for four days to study the Malayan National Development Programme. They were Brigadier General Jung Moo Kim, Director General for Plans and Control in the Office of Prime Minister of South Korea, and Colonel Jwah Kyum Kim, Planning Coordinator under General Jung. 18 They were impressed with the implementation of Malaysia's national development policy. According to General Jung, "We [sic] ourselves have started a five year plan which ends in 1966 and hope to pick up more ideas during the tour'.19 It is not far-fetched to claim that the Koreans learned immensely from Malaya's rural development programme to eventually implement their own, namely the Saemaul Undong or the New Village Movement. It was a political initiative launched on April 22, 1970 by Korean President Park Chung-Hee to modernize the rural economy of the South.

The idea was based on the Korean traditional communalism called Hyangyak and Doorae which provided the rules for self-governance and cooperation in traditional Korean communities. The programme was, therefore, aimed at improving the livelihood of villagers by reducing the gap between rural and urban life, improving the living standards in the rural areas and increasing the opportunities for the villagers to earn more.20 Under the programme, the government distributed 335 bags of cement to each village for small developmental projects. The cements were used by villagers, who also built roads, drains and houses using their own cash and labour. A massive rice procurement policy - at prices several times the world market price - was also initiated to support farm income.

\section{International Backdrop of Malaysia-South Korea Economic Relations in the 1970s}

The 1970s witnessed the strong emergence of non-aligned movement as an influential trend in international politics. Changes in international and regional politics called for policy accommodation by both South Korea and Malaysia for a more effective pursuit of their national objectives. The repercussion of international politics and Malaysia's adherence to non-aligned countries' neutralism and non-aligned principle had a profound impact on South Korea-Malaysia relations.

As Malaysia was uncomfortable with political labeling, especially that which linked the country as a Western ally, Tun Abdul Razak, who took over in 1970 as Prime Minister,

\footnotetext{
17 Brig. Gen. Ibrahim was a Malayan soldier who served in the British Special Operations Executive (SOE) during World War II, subsequently rising to the post of Chief of the Malaysian Defence Forces from 1971 until 1977. See J. Robertson, "Ibrahim bin Ismail”, Special Forces Roll of Honour, 2013, http://www.specialforcesroh.com/showthread.php?40621.

18 “Koreans Fly in to See Progress", New Straits Times, 27 October 1962. 19 New Straits Times, 27 October 1962.

20 See D. Arroyo, The Political Economy of Successful Reform: Asian Stratagems, Stanford, Centre for International Development, 2008.
} 
adjusted the direction of Malaysia's foreign policy.21 The changing geo-political configuration, such as the phasing out by the British of their military commitments in Southeast Asia, also caused Kuala Lumpur to move away from its traditionally close links with London.22 In the 1970s, Malaysia decided to move closer to the non-aligned nations and to pay greater attention to emerging regional groupings, particularly the Association of Southeast Asian Nations (ASEAN).23 In 1970, Malaysia was admitted into the Non-Aligned Movement (NAM).24 In keeping with this new stance of foreign policy, Kuala Lumpur recognized North Korea on 2 July 1973. As a result, Kuala Lumpur had to maintain an equidistant stance from both Seoul and Pyongyang.

\section{Malaysian Economic Policies during Tun Razak and Tun Hussein Onn's Era}

Before 1970, the main focus of Malaysia's development policy was stimulating growth, stressing on the importance of the export market. The core economic plan was to promote the growth of traditional and new export opportunities, while industrialization had already taken off with the establishment of petroleum refineries, mills and plants.25 As a result, the economy flourished at $6.0 \%$ annually on the average during this period. However, there was insufficient emphasis on the aspects of distribution and this resulted in uneven socioeconomic development among the different ethnic groups. This inequity resulted in a negative social development between the majority and minority races. This resulted in a racial riot in 1969. The Malaysian government decided to address the disparity by introducing the New Economic Policy (NEP), which was an affirmative action plan to the improve the economic position of native Malays vis-à-vis the other ethnic groups, especially the Chinese. The main aim of the NEP was to restructure the economy over two decades, from 1970 to 1990.26 The

21 K. Pollard, “ASA and ASEAN, 1961-1967: Southeast Asian Regionalism”, Asian Survey, Vol. 10, No. 3, 1970 , pp. 244-255.

22 J. Saravanamuttu, “ASEAN in Malaysian Foreign Policy Discourse and Practice, 1967-1997”, Asian Journal of Political Science, Vol. 5, No. 1, 1997, pp. 35-51.

23 See J. Saravanamuttu, Malaysia's Foreign Policy: The First Fifty Years: Alignment, Neutralism, Islamism, Singapore: Institute of Southeast Asian Studies, 2010.

24 D. Jain and S. Shubha Chacko, "Walking Together: The Journey of the Non-Aligned Movement and the Women's Movement", Development in Practice, Vol. 19, No. 7, 2009, pp. 895-905.The Non-Aligned Movement (NAM) is a group of states that are not formally aligned with or against any major power bloc. It was established in 1961 in Belgrade, Yugoslavia. An initiative of Yugoslav president Josip Broz Tito and Indian Prime Minister Jawaharlal Nehru led to the first Conference of Heads of State or Government of Non-Aligned Countries. The purpose of the organization has been enumerated as to ensure "the national independence, sovereignty, territorial integrity and security of non-aligned countries" in their "struggle against imperialism, colonialism, neo-colonialism, racism, and all forms of foreign aggression, occupation, domination, interference or hegemony as well as against great power and bloc politics," by Fidel Castro in his Havana Declaration of 1979. The countries of the Non-Aligned Movement represent nearly two-thirds of the United Nations' members and contain $55 \%$ of the world population. Membership is particularly concentrated in countries considered to be developing or part of the Third World, though the Non-Aligned Movement also has a number of developed nations.

25 First Malaysia Plan, 1966-1970, Kuala Lumpur: Government Press, 1965, p. 9.

26 J.K. Sundaram, The New Economic Policy and Interethnic Relations in Malaysia, Geneva: United Nations Research Institute for Social Development (UNRISD), 2004. 
Second Malaysian Plan was introduced under Tun Razak to increase Malay participation in the economy, especially in manufacturing and mining. 27

The statistics in Table 1 show that Government efforts prior to the NEP succeeded in reducing absolute poverty (represented by poverty incidence) among the Malays. However, income inequality (measured by both the Gini coefficient and the percentage share of income of the bottom $40 \%$ of the group) increased for all ethnic groups, with the fastest being among the Malays. Moreover, several government agencies had been established prior to Tun Razak administration to encourage Malay participation in the economy.

Table 1: Income Distribution by Ethnic Groups in Peninsular Malaysia, 1957-1970

\begin{tabular}{|l|l|l|l|}
\hline & $\mathbf{1 9 5 7 / 5 8}$ & $\mathbf{1 9 6 7 / 6 8}$ & $\mathbf{1 9 7 0}$ \\
\hline Malay & & & \\
\hline Mean income, RM/month, 1959 prices & 134 & 154 & 170 \\
\hline Gini coefficient & 0.342 & 0.400 & 0.466 \\
\hline \% share of income of bottom 40\% & 19.5 & 17.2 & 12.7 \\
\hline Poverty incidence & 70.5 & & 65.9 \\
\hline Chinese & & & \\
\hline Mean income, RM/month, 1959 prices & 288 & 329 & 390 \\
\hline Gini coefficient & 0.374 & 0.391 & 0.455 \\
\hline \% share of income of bottom 40\% & 18.0 & 17.0 & 13.9 \\
\hline Poverty incidence & 27.4 & & 27.5 \\
\hline Indian & & & \\
\hline Mean income, RM/month, 1959 prices & 228 & 245 & 300 \\
\hline Gini coefficient & 0.347 & 0.403 & 0.463 \\
\hline \% share of income of bottom 40\% & 19.7 & 16.3 & 14.3 \\
\hline Poverty incidence & 35.7 & & 40.2 \\
\hline Chinese: Malay average income ratio & 2.16 & 2.14 & 2.29 \\
\hline Indian: Malay average income ratio & 1.71 & 1.60 & 1.75 \\
\hline
\end{tabular}

Source: Muniappan Perumal. (1989). Economic-Growth and Income Inequality in Malaysia, 1957-1984. Singapore Economic Review, 34 (2) , pp. 33-46 and Donald R. Snodgrass. (1995). Successful Economic Development in a Multi-Ethnic Society: The Malaysian Case. Cambridge: Harvard Institute for International Development, Harvard University.

These agencies include the Malaysian Industrial Development Authority (MIDA) and Majlis Amanah Rakyat (MARA).28 Several more were also established under Tun Razak's economy plan, including the Perbadanan Nasional (PERNAS, or the National Trading Corporation), State Economic Development Corporation and the Urban Development Authority (UDA).

In agriculture, the focus was given on diversifying crops grown in Malaysia. Doublecropping of rice was encouraged, so that farmers could harvest twice in one year and effectively double their output.29 The Farmers' Organization Authority (FOA) was established

27 See V. Nena, Area Handbook for Malaysia: No. 3, Washington, D.C: American University Foreign Area Studies, 1977.

28 Dewan Rakyat (Lower House) Report (19 July 1973), Rang Undang-Undang Majlis Amanah Rakyat (Pindaan) [Majlis Amanah Rakyat Bill (Amended), Penyata Dewan Rakyat (Hansard), p. 2548.

29 E.C. Daño and E.D. Samonte, Public Sector Intervention in the Rice Industry in Malaysia, Quezon City: Southeast Asia Regional Initiatives for Community Empowerment (SEARICE), 2005. 
in 1973 with the goal of co-ordinating agricultural cooperatives, farmers' associations, and government agricultural agencies. 30 Growth in small-scale agriculture was viewed as crucial to creating jobs and reducing rural poverty. Government agencies such as the Federal Land Development Authority (FELDA) increased the scope and size of their development programs. The Rubber Industries Smallholder Development Agency (RISDA) was given the task of diversifying smallholder estates. It set itself the ambitious goal of developing 150,000 acres $(610 \mathrm{~km} 2)$ during the Second Malaysia Plan. The main aim was to diversify the economy by producing palm oil, as the Malaysian economy relied heavily on rubber. By the end of the Second Malaysia Plan, 40,000 acres $(160 \mathrm{~km} 2)$ were developed, with almost half of this number comprising oil palm plantations.31

Tun Razak also aimed to modernise Malaysian railroads, which he regarded as crucial to development and industrialization. All trains were converted to use the more efficient diesel fuel, and the government increased allocations for maintenance and modernisation of the rail infrastructure. Emphasis was placed on upgrading existing rolling stock, roadbeds, and repair facilities.32 In 1976, Hussein Onn, the third Prime Minister, proposed the Second Phase of the Third Malaysia Plan (RMK 3) in the implementation of the NEP to continue efforts to strengthen national unity and eradicate poverty irrespective of race, and bolster national security. 33 The plan was designed to gain advantage by improving global trade. In order to improve the productivity of the poor in agricultural areas, new lands were opened and developed as settlements. This provided job opportunities for those who were landless or owned land but did not have the financial capacity to develop. Large tracts of paddy lands were also opened for cultivation, as Tun Hussein Onn had previously remarked in 1974 that local food production had to be increased in the face of an impending recession. 34 Apart from that, the development of Perlis, Kedah, Kelantan, Terengganu, Malacca, Sabah and Sarawak was also equally prioritized to reduce economic disparity among the states. The government also continued to increase the allotment of capital shares for the Malays and other Bumiputera races.

Overall, under the Tun Razak administration, the poverty rate declined from $49 \%$ to $43 \%$ and unemployment improved, decreasing from $7.5 \%$ to $7.4 \% .35$ Great strides were made

30 Farmers' Organization Authority was founded on 14 February 1973 through the gazetting of Lembaga Pertubuhan Peladang 1973 Act (Act 110). Farmer's Organization Act (FOA) was estableihed to carry the responsibility of helping to strengthen the social and economy of agricultural communities under a specific body with specific functions.

31 Yahaya Ibrahim and Abdul Rasid Abdul Razzaq, "Homestay Program and Rural Community Development in Malaysia” Journal of Ritsumeikan Social Sciences and Humanities, Vol. 2, No, 3, 2010, pp. 7-24. See also S. Anand, Inequality and Poverty in Malaysia: Measurement and Decomposition, New York: Oxford University Press, 1983.

32 Zakaria Haji Ahmad, "Malaysia in 1980: A Year of Political Consolidation and Economic Development", Southeast Asian Affairs, 1981, pp. 201-216. See also Tiong An Chua, "Transport in Malaysia. Transport Reviews", Vol. 3, No. 3, 1983, pp. 207-235.

33 "Malaysia's Development Plans and Policies (1956-Present)", http://www.perdana.org.my/pms-ofmalaysia/visual-timelines/malaysia-s-development-plans-policies.

34 Speech by Tun Hussein On, Rang Undang-Undang Perbekalan (Supply Bill), Penyata Dewan Rakyat (Hansard), 12 November 1974, pp. 498-524.

35 Ishak Shari, "Economic Growth and Income Inequality in Malaysia, 1971-95", Journal of the Asia Pacific Economy, Vol. 5, No. 1-2, 2000, pp. 112-124. See also Kamal B. Sali, and Mei Ling Young, Structural Adjustment, Employment Policy and Unemployment in Malaysia, Kuala Lumpur: Malaysian Institute of Economic Research, 1988. 
in increasing Bumiputera involvement in the private sector. Their employment rate in the manufacturing sector increased from $29 \%$ to $33 \%$, and from $24 \%$ to $34 \%$ in the commercial sector (Mei Ling Sieh Lee, 1982). Between 1972 and 1975, the consumer price index (CPI) increased by $40 \%$. In 1974, the inflation rate averaged $18 \%$, but was reduced to $7 \%$ by 1975 (Mansor Jusoh, 1986, pp. 87-103). Tun Hussein Onn was especially renowned for stressing national unity through rectifying economic imbalances between the various communities in Malaysia. From 1976-1981, Malaysia's GDP in rose from $\$ 877.02$ at the initial phase of the 3rd Malaysia Plan to $\$ 1,770.17$ by the end of the period. Tun Hussein Onn's most profound legacy was the establishment of Amanah Saham Nasional scheme 1981 (Sundaram, 1994). Through this scheme, government-owned shares were transferred to the Bumiputeras so that they can make large profits at the stock market. He also oversaw the establishment of the Permodalan Nasional Berhad (PNB), an organ for the government to acquire controlling stake in both local and foreign companies. 36

In the international environment, Malaysia continued to focus on non-alignment and regional neutrality. At the Summit in Bali in 1976, ASEAN adopted two important documents - the Declaration of ASEAN Concord and the Treaty of Amity and Cooperation (TAC).37 TAC was significant because it provided the mechanisms for dispute settlement between members. ASEAN's twofold ideology of non-intervention and mutual respect for the territorial integrity of member states' are enshrined in TAC. Accordingly, under Tun Hussein Onn, Malaysia continued to make peace overtures to the Communist Indochinese countries.

It is within this backdrop of strong economic position and regional cooperation that Malaysia pursued its bilateral relations with South Korea. During the period of 1973 to 1977, South Korea accounted an average of 0.4 percent per year of Malaysia's total imports requirements. In terms of value, Malaysia's imports from Korea increased from about RM18 million in 1973 to RM85.3 million in 1977 (see Table 2). The major products that constituted Malaysia's imports from South Korea included textile fabrics, medical and pharmaceutical products, fertilizers, cements, and paperboard.

Table 2: Malaysian Trade with South Korea

\begin{tabular}{|l|c|c|c|c|}
\hline Year & Exports & Imports & $\begin{array}{l}\text { Total } \\
\text { Trade }\end{array}$ & $\begin{array}{l}\text { \% of } \\
\text { Malaysia's } \\
\text { Total } \\
\text { Trade }\end{array}$ \\
\hline 1973 & 164.87 & 18.04 & 182.91 & 1.38 \\
\hline 1974 & 178.67 & 63.43 & 242.1 & 1.21 \\
\hline 1975 & 153.7 & 35.1 & 188.8 & 1.05 \\
\hline 1976 & 241.5 & 66.4 & 307.9 & 1.33 \\
\hline 1977 & 255 & 85.3 & 340.3 & 0.64 \\
\hline 1978 & 303 & 133.5 & 436.5 & 1.41 \\
\hline 1979 & 118.8 & 170.2 & 289 & - \\
\hline
\end{tabular}

Source: Malaysian Investment Development Authority, 1973-1979

${ }_{36}$ R. Rasaih and Ishak Shari, "Market, Government and Malaysia's New Economic Policy", Cambridge Journal of Economics, Vol. 25, No. 1, 2001, pp. 57-78. See also L. Rethel, "Financialisation and the Malaysian Political Economy. Globalizations", Vol. 7, No. 4, 2010, pp. 489-506.

37 S. Sharpe, “An ASEAN Way to Security Cooperation in Southeast Asia?”, The Pacific Review, Vol. 16, No. 2, 2003, pp. 231-250. 
As shown in Table 3, primary commodities formed the bulk of Malaysian exports to South Korea, whiles its imports consisted mostly of manufactured goods. For instance, in 1970, 98 percent of the exports to Korea consisted of crude materials. Of this, 87 percent consisted of saw logs and sawn timber and 11 percent natural rubber. Malaysia did export about 4 percent of the manufactured goods to South Korea. These were primarily tin-based manufactured articles such as pewter and other alloys. On the other hand, Malaysia's imports from South Korea were mostly manufactures goods, of which 80 percent were clothing and textiles. Overall, during the period of Tun Abdul Razak and Tun Hussein Onn, Malaysia's trade relations with South Korea were mainly on the basis of exporting raw materials to South Korea. Malaysian imports only included manufactured goods under their leadership.

Table 3: Malaysia Trade Flows by Commodity Groups 1970, 1980

\begin{tabular}{|c|c|c|c|c|}
\hline & \multicolumn{2}{|l|}{1970} & \multicolumn{2}{|l|}{1980} \\
\hline Products & Exports & Imports & Exports & Imports \\
\hline Food and animals & 0 & 18 & 4 & 2 \\
\hline $\begin{array}{l}\text { Beverages and } \\
\text { tobacco }\end{array}$ & 0 & 9.1 & 0 & 0.3 \\
\hline Crude Materials & 98 & 9.9 & 86.8 & 2 \\
\hline Mineral Fuels & 0 & 0 & 0 & 0.1 \\
\hline $\begin{array}{l}\text { Animal and } \\
\text { Vegetable Oils }\end{array}$ & 0 & 0 & 3.6 & 0 \\
\hline Chemicals & 0 & 1.5 & 0.1 & 6.1 \\
\hline $\begin{array}{l}\text { Manufactured } \\
\text { Goods }\end{array}$ & 3.5 & 46.7 & 7.8 & 54.4 \\
\hline $\begin{array}{l}\text { Machinery and } \\
\text { Transport }\end{array}$ & 0 & 0.5 & 0.8 & 22.3 \\
\hline $\begin{array}{l}\text { Miscellaneous } \\
\text { Manufactured } \\
\text { articles }\end{array}$ & 0 & 14.2 & 0.1 & 8.4 \\
\hline $\begin{array}{l}\text { Miscellaneous } \\
\text { Transactions }\end{array}$ & 0.5 & 0.1 & 0.4 & 4.4 \\
\hline
\end{tabular}

Source: Department of Statistics, Malaysia, External Trade Statistics, Various Issues.

Foreign Direct Investment (FDI) was also important in Malaysia's economic growth and development. It has contributed significantly to the economic development of Malaysia. The first recorded South Korean investment to Malaysia was in 1973, by Hanjin Construction and four years later by Daewoo Cooperation. South Korea's investment in Malaysia during these years was predominantly in resource-based industries, such as non-metallic mineral products, wooden and wood-based products, as well as furniture and fixtures. The bulk of it took the form of 100 percent foreign equity or majority foreign ownership. This might have stemmed from Malaysia's biased export promotion investment policy guidelines, which call 
for local ownership for projects.38 Among the biggest investment from 1973 was for cement mixing by DOOSAN Heavy Industry with net accumulative investment worth US\$24 million. This project was a collaborative effort with a local Malaysian company, it was named as Perak-Hanjoong Simen Sdn. Bhd ("Malaysia-Korea Economic Relations: Trends and Developments").39 Most of South Korean investments were in the form of joint ventures with Malaysian companies. In 1974, the Korean Development Corporation was awarded the contract, amounting to US\$31 million, to build 3 of the 5 major bridges along the East-West highway. The bridges were built across Sungai Rui (842 ft -3 million), Sungai Perak Reservoir (2,88ft - 17 million); Sungai Perak Causaway 2,294 ft-11 million).40 In 1978, the Koreans were also involved in a number of major projects that required their expertise. These projects included the Federal highway, the irrigation scheme in Besut, the Karak Tunnel, Penang Airport, and a major bridge along East-West highway, Rejang Port in Sarawak and an oil palm refinery in Sabah.41

The Korean ambassador to Malaysia clearly stated his country would assist Malaysia to achieve its Third Malaysian Plans, especially in manufacturing, agriculture, fishery and mining industry. 42 The South Koreans accordingly sent 20 experienced civil engineers to implement the Ministry of Public Works' plan under Third Malaysian Plan.43 Malaysia even secured \$9.2 million loan from South Korea between 1971 and 1975 to develop its Third Malaysian Plan.44 By the end of 1979, Table 4 indicates that a total of 9 projects with Korean interest were approved, but only 2 companies were in production i.e., S.K.P. Gelas Sdn. Bhd and Malhan Textiles (M) Sdn. Bhd.45

Among the Korean companies which entered into joint-ventures with Malaysia were Tae-Yang Woodwork Co. Ltd., Kyung Duh Manufacturing Co. Ltd., Hyundai International Incorporated and Pyeong Hwa Clutch Manufacturing Co. Ltd. Korean investments were in the manufacture of cement, glass and glass products, manufacture of motor vehicles parts and accessories and panel and curved doors.46 It has to be noted the development authorities in Malaysia like DARA, Jengka, Kesedar and Ketengah were willing to promote integrated timber processing complexes at their respective states with South Korean investors. 47

${ }_{38}$ See V. Kanapathy, Industrial Restructuring in Malaysia, in Chia Siow Yue, Donna Vandenbrink and Seiichi Masuyama, eds, Industrial Restructuring in East Asia: Towards the 21st Century, Singapore: Institute of Southeast Asian Studies, 2001.

39 "Malaysia-Korea Economic Relations: Trends and Developments", http://cefia.aks.ac.kr:84/index.php?title=Malaysiakorea_Economic_Relations:_Trends_and_Developments.

40 "Korean Firm Wins Bridge Contract", New Straits Times, 5 February 1974.

41 "Closer Ties our Aim, Says Envoy", New Straits Times, 1 October 1978.

42 "Pursuing Peace, Stability and Work Together for Development, Message from Mr. Sanggin Chyun, Korea's Ambassador to Malaysia”, New Straits Times, 2 October 1977.

${ }_{43}$ "Seoul asked to send engineers for Malaysian Plan", New Straits Times, 28 April 1977.

44 Third Malaysian Plan, 1976-1980, Kuala Lumpur: Government Press, 1976, p. 252.

45 Ibid.

46 Ibid.

47 Ibid. 
Table 4: South Korean Investment Companies and Products Manufactured in Malaysia as of March 1980

\begin{tabular}{|c|c|c|c|}
\hline $\begin{array}{l}\text { Address of } \\
\text { Company }\end{array}$ & Products Manufactured & Foreign Partner & Factory Location \\
\hline $\begin{array}{llr}\text { S.K.P. } & \text { Gelas } & \text { Sdn. } \\
\text { Bhd. } & 149, & \text { jalan } \\
\text { Birch, } & \text { Kuala Lumpur } \\
\end{array}$ & $\begin{array}{l}\text { 1. Lamp shades } \\
\text { 2.Chandeliers } \\
\text { 3. Fancy glassware } \\
\end{array}$ & $\begin{array}{l}\begin{array}{l}\text { Mr. Kim Dai Sung } \\
\text { (provide }\end{array} \\
\text { know-how) }\end{array}$ & Shah Alam, Selangor \\
\hline $\begin{array}{l}\text { Tae Yang Woodwork } \\
\text { Co. (M) Sdn.Bhd., } \\
\text { Lot 4, Jalan 200, } \\
\text { Petaling Jaya }\end{array}$ & $\begin{array}{l}\text { 1. Panel and curved } \\
\text { doors }\end{array}$ & $\begin{array}{l}\text { Tae-Yang Woodwork } \\
\text { Co. Ltd. }\end{array}$ & $\begin{array}{l}\text { North Klang Straits, } \\
\text { Klang, Selangor }\end{array}$ \\
\hline $\begin{array}{l}\text { Malhan Textiles (M) } \\
\text { Sdn. Bhd., 260, Brick } \\
\text { Kiln Road, Penang. }\end{array}$ & $\begin{array}{l}\text { 1. Glassware and } \\
\text { Decorative/Fancy } \\
\text { Glasware } \\
\end{array}$ & N.A. & $\begin{array}{lcc}\text { Prai, } & \text { Free } & \text { Trade } \\
\text { Zone, } & \text { Penang } & \end{array}$ \\
\hline $\begin{array}{lr}\text { Chuan } & \text { Electrical } \\
\text { Industries } & \text { Sdn. Bhd., } \\
98 / 50, & \text { Gedong } \\
\text { Lalang, Seremban, } & \text { Negeri Sembilan }\end{array}$ & 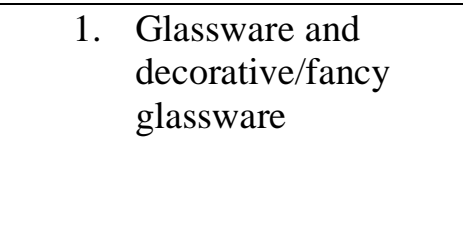 & N.A. & $\begin{array}{ll}\text { Senawang, } & \text { Negeri } \\
\text { Sembilan } & \end{array}$ \\
\hline $\begin{array}{lr}\text { Senawang Gelas Sdn. } \\
\text { Bhd., } 1_{\text {st }} & \text { Floor, 74, } \\
\text { Jalan } & \text { Pahang, } \\
\text { Seremban, } & \text { Negeri } \\
\text { Sembilan } & \\
\end{array}$ & $\begin{array}{l}\text { 1.Glass tableware } \\
\text { 2.Ornamental/decorative } \\
\text { glassware }\end{array}$ & N.A. & $\begin{array}{l}\text { Senawang, Negeri } \\
\text { Sembilan }\end{array}$ \\
\hline $\begin{array}{l}\text { Perak Halla Cements } \\
\text { Sdn.Bhd. }\end{array}$ & $\begin{array}{l}\text { 1. Portland Cement and } \\
\text { Clinkers }\end{array}$ & $\begin{array}{l}\text { Hyundai Internatioal } \\
\text { Incorporated }\end{array}$ & $\begin{array}{l}\text { Mk. Kampong } \\
\text { Buaya, Perak }\end{array}$ \\
\hline $\begin{array}{l}\text { Automotive Products } \\
\text { Sdn. Bhd. 54, Green } \\
\text { lane, Penang }\end{array}$ & $\begin{array}{l}\text { 1. Clutch discs } \\
\text { 2. Clutch tubings }\end{array}$ & $\begin{array}{l}\text { Pyeong Hwa Clutch } \\
\text { Manufacturing Co. } \\
\text { Ltd. }\end{array}$ & Prai, Penang \\
\hline $\begin{array}{l}\text { Dongkuk-Techno } \\
\text { Rubber Industries } \\
\text { Sdn.Bhd. Suite 710, } \\
\text { 7th Floor Fitzpatrick's } \\
\text { Building, 86, jalan } \\
\text { Raja Chulan, Kuala } \\
\text { Lumpur }\end{array}$ & $\begin{array}{l}\text { 1. Prophylactics and } \\
\text { finger cots }\end{array}$ & $\begin{array}{l}\text { Dongkuk Trading Co. } \\
\text { Ltd. }\end{array}$ & $\begin{array}{lr}\text { Bakar } & \text { Arang } \\
\text { Industrial } & \text { Estate, } \\
\text { Kedah } & \end{array}$ \\
\hline $\begin{array}{lr}\text { Bunco } & \text { Crayon } \\
\text { Industrial Co. Ltd., } & \\
\text { c/0 Amanah-Chase } \\
\text { Merchant Bank Bhd., } \\
9 \text { th } \\
\text { Fitzpatrick's } \\
\text { Building, Jalan Raja } \\
\text { Chulan, } \\
\text { Lumpur }\end{array}$ & $\begin{array}{ll}\text { 1. } & \text { Artificial wax } \\
\text { 2. } & \text { Oil pastels } \\
\text { 3. } & \text { Crayons } \\
\text { 4. } & \text { Sign pens } \\
\text { 5. } & \text { Water colours } \\
\text { 6. } & \text { Sliding pencils } \\
\text { 7. } & \text { Pencil slats }\end{array}$ & $\begin{array}{l}\text { Dong A Pencil Co. } \\
\text { Ltd. }\end{array}$ & North Klang Straits \\
\hline
\end{tabular}

Source: South Korean Investment in Malaysia as at March, 1980. File 18, 1987/0015734, National Archives, Malaysia 
The balance of trade between Malaysia and the South Korea remained in Malaysia's favor. Over the years, Malaysia's exports to the South Korea expanded at a faster rate than the imports.48 Therefore, the surplus in the balance of trade increased from RM146.8 million in 1973 to RM170.1 million in 1987.

Figure 1: Korean Trade with Malaysia, 1970-1980 (USD million)

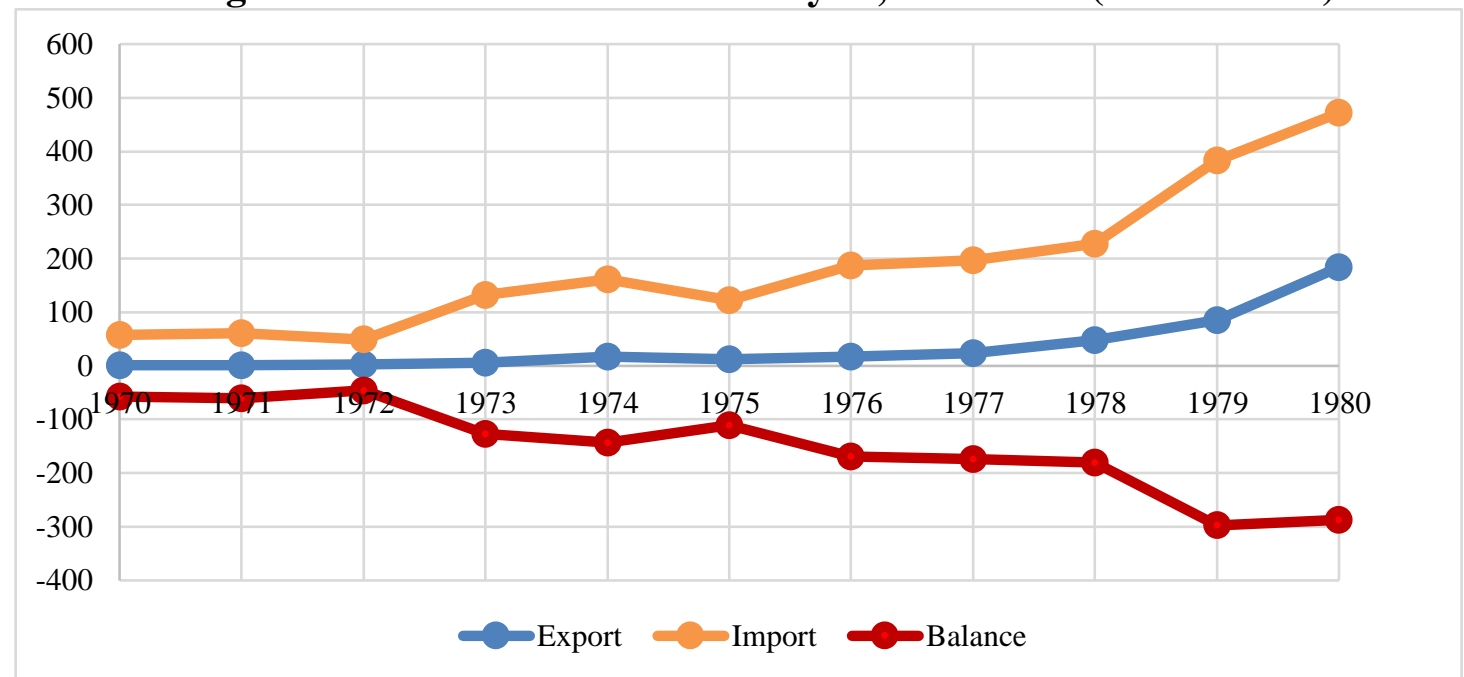

Source: Foreign Trade Association of Korea, The Trend of Foreign Trade, various issues, 1990-1980

Table 5: Malaysian Trade with South Korea

\begin{tabular}{|c|c|c|c|c|}
\hline Year & $\begin{array}{c}\text { Exports } \\
\text { (RM million) }\end{array}$ & $\begin{array}{c}\text { Imports } \\
\text { (RM million) }\end{array}$ & $\begin{array}{c}\text { Total Trade } \\
\text { (RM million) }\end{array}$ & \% of Malaysia's Total Trade \\
\hline 1973 & 164.87 & 18.04 & 182.91 & 1.38 \\
\hline 1974 & 178.67 & 63.43 & 242.1 & 1.21 \\
\hline 1975 & 153.7 & 35.1 & 188.8 & 1.05 \\
\hline 1976 & 241.5 & 66.4 & 307.9 & 0.64 \\
\hline 1977 & 255 & 85.3 & 340.3 & 1.41 \\
\hline 1978 & 303 & 133.5 & 436.5 & - \\
\hline 1979 & 118.8 & 170.2 & 289 & 1.33 \\
\hline
\end{tabular}

Source: Malaysian Investment Development Authority, 1973-1979

48 Since the early 1960s, the structural pattern of imports showed changes, particularly in the relatively decreasing share of imported consumer goods and the accelerated growth of industrial supplies and capital equipment imports. The share of consumer goods imported in 1962 was 24.1 percent of total imports; this share declined to 9.8 percent of total imports in 1986 because of increased South Korean production of these goods for the domestic market. The declining share of raw materials as a percentage of imports during the early 1970s was reversed in 1974 because of the increased value of oil imports (caused by the 1973 war in the Middle East). By 1979 crude oil was 25 percent of South Korea's total import requirements. 
As shown in Figure 1, South Korea's exports to Malaysia in 1979 reached US\$85.8 million, while Malaysian exports to South Korea amounted to US\$383.2 million. Although the total volume was not meaningful enough, the increased two-way trade between the two countries was particularly a noteworthy achievement during the 1970s. Between 1970 and 1979, Malaysia's trade volume increased more than six times, while South Korea's exports to Malaysia increased even more dramatically - more than 80 times.49

During Tun Hussein Onn's official visit to South Korea from 16 to 20 July 1979, both Prime Ministers noted with satisfaction the steady increase in trade and economic exchanges (Joint Communique between The Honourable Dato' Hussein Bin Onn Prime Minister of Malaysia and His Excellency Choi Kyu Hah Prime Minister of the Republic of Korea). They agreed that both governments would continue their endeavors to further expand bilateral and direct trade as well as economic and technical cooperation.50 They also agreed to meet each other's demand for the stable and reliable supply of industrial raw materials, such as timber, rubber, tin, palm oil, and energy resources including petroleum and agricultural products on a mutually beneficial basis.51 Hussein Onn expressed the Malaysian government's satisfaction over the successful joint ventures, especially in construction projects, between the two countries and invited more active South Korean participation in the development projects in Malaysia. Prime Minister Choi stated that the South Korean Government would continue to encourage such participation by the Korean private sector. Both Prime Ministers also discussed prospects for joint ventures in resource-based industries and agreed that the feasibility of such proposal should be examined by officials of both countries. Cooperation in technology and capital were especially important undertaking towards strengthening bilateral cooperation. To these end, they agreed that two governments should hold regular high-level talks on economic, financial, trade and other matters. It was also expected that the Convention between Malaysia and the Republic of Korea for Avoidance of Double Taxation would be concluded at the earliest possible date. The two Prime Ministers also agreed on the need for exchanges of personnel and other contacts between both countries and the need to have exchanges of visits including youth and students of two countries. 52

The visit was followed by an official visit by Dato Seri Dr. Mahathir Mohamad, then Malaysia's Deputy Prime Ministera and Minister of Trade and Industry, from 5 to 11 October 1980.53 This visit led to a meeting on Bilateral Trade and Industrial Cooperation between both countries. The following areas were indicated as investment possibilities in Malaysia:

i. $\quad$ Processing and manufacture of resource - based products utilizing, for example, wood, rubber, tin, pepper, sand and clay.

ii. Manufacture of petrochemicals and other chemical products.

49 Mid-Term Review of the Third Malaysia Plan, 1976-1980, Kuala Lumpur: Government Press, 1979, p. 78. 50 Joint Communique between The Honourable Dato' Hussein Bin Onn Prime Minister of Malaysia and His Excellency Choi Kyu Hah Prime Minister of the Republic of Korea, File 2000/0015899, National Archives of Malaysia, p. 2.

51 Ibid., p. 4.

52 Ibid.

53 Report on the official visit of YAB Deputy Prime Minister, dato Seri Dr. Mahathir bin Mohamad to the Republic of Korea from the 5th to the 11th October 1980. File No. 1987/0015734, National Archives of Malaysia, p. 4. 
iii. Manufacture of precision products, for example, musical instruments, photographic abd optical goods, watches and clocks, cutting and polishing of precious stones, manufacture of jewelries etc.

iv. Manufacture of industrial machinery and parts.

v. Manufacture of medical and scientific equipment.

vi. Manufacture of electronics and electrical appliances or equipment and components.

vii. Manufacture of all types of footwear and toys.

It was agreed that the Ministry of Trade and Industry would disseminate the list to the South Korean business community, inviting them to explore the possibility of joint venturing in Malaysia. By the end of June 180, a total of 9 projects with South Korean interests were approved.

Chun Doo Hwan, the South Korean President, visited Malaysia from 29 June to 1 July 1981. Both him and Dato' Hussein Onn agreed to further strengthen bilateral relations (Joint Communique Between His Excellency Chun Doo Hwan, President of the Republic of Korea and the Hon'ble Dato Hussein Onn, Prime Minister of Malaysia, Kuala Lumpur, 1st July, 1981). The two leaders noted with satisfaction that the bilateral relations between the Republic of Korea and Malaysia had been strengthening particularly since the official visit of the Malaysian Prime Minister to South Korea in July 1979. This is evidenced by the growth of bilateral trade and economic cooperation, the regular participation of the South Korean private sector in Malaysia's development projects.54 Tun Hussein Onn briefed the South Korean President on the objectives and scope of the Fourth Malaysian Plan in terms of their attractions to foreign participation in Malaysia's economic development through investments, technical cooperation and joint venture projects. He expressed hope that South Korea with its advanced economic and technological development could extend assistance, involving transfer of technologies in power development projects, development of alternative sources of energy, construction projects, cooperation in resource-based industries, manufacturing and processing industries in Malaysia. 55

To this end, Tun Hussein Onn noted with satisfaction the participation of the Korean private sector in Malaysia's development projects particularly in the construction field. He invited the South Korean private sector to take the opportunity of the availability of abundant natural resources including labour and energy in Malaysia to set up joint ventures, particularly in resource-based industries like rubber and wood processing. President Chun then expressed his government's readiness to continue to encourage the active participation of South Korean private sector in joint venture projects. Following that, the two leaders noted that the Korean-Malaysia Economic Cooperation Committee on the private level would serve as a forum for promoting participation by the private sector in such endeavors. 56

Additionally, President Chun expressed appreciation for Malaysia's cooperation in providing a stable supply of natural resources, including energy resources, timber, rubber and tin. He was assured that Malaysia would continue to assist Korea in securing a smooth supply of such resources. In this regard, both leaders agreed that they would hold consultations talks,

54 Joint Communique between Chun Doo Hwan and Hussein Onn.

55 Ibid.

56 Ibid. 
within the purview of existing annual policy, between senior officials of both countries with a view to promote bilateral cooperation in the field of natural resources. 57

The two leaders also agreed to closely cooperate in the conduct of joint survey on fishery resources, training of fishery staffs and fishermen, management personnel of the industry and provision of necessary expertise and exchange of scientific in respect of both capture fishery and aquaculture. They further agreed to encourage joint ventures in fishing industries with the private sector and to enter into negotiation for an early conclusion of fisheries agreement. The South Korean President also expressed his willingness to cooperate and assist in the rural and agricultural development of Malaysia. He offered the services of South Korean experts involved the Saemaul Undong project.58 Both leaders agreed to sign the Agreement for Avoidance of Double Taxation and to hold negotiations for an early conclusion of an Investment Guarantee Agreement between both countries. The President and the Prime Minister agreed that in order to boost the growth of trade and to increase industrial cooperation, the Ministers of Trade and Industry of both countries would hold regular bilateral consultation meetings on matters of trade and industry.

\section{Conclusion}

This article has postulates that Malaysia established a robust bilateral economic relations on a mutually beneficial basis from the era of Tunku Abdul Rahman onwards. In the 1960s, the South Koreans learnt from Malaysia's agricultural program to develop their own 5-year development programme. During Tun Razak's tenure as the Prime Minister, Malaysia continued its role as a supplier of raw materials to Korea. Malaysia, on the other hand, imported products such as textile, agricultural and marine products for domestic use. Bilateral cooperation was further strengthened with the conclusion of a series of agreements, including the Trade Agreement in 1962, Cultural Agreement in 1965, Aviation Agreement 1967 and Agreement on Prevention of Double Taxation in 1980. It was during Tun Hussein Onn's era that there was a drastic change in the relation. South Koreans began to be confident enough to invest in Malaysia's industrial and infrastructure projects. Many roads were built with through joint ventures between South Korean private sector and local Malaysian industry players.

However, Malaysia-South Korea economic relations in the early 1960s could only be considered as cordial, with no significant strides made in bilateral trade other than Malaya supplying raw materials for South Korea's industrialization projects. In actuality, both countries did not view each other as significant political or economic partner. This was to be expected, as both were relatively small countries with modest economic and strategic importance, separated by vast distances, and preoccupied with domestic and external geopolitical demands. Therefore, South Korea and Malaysia paid more attention to relations with countries whose support and collaboration they considered essential for their national well-being in terms of national security and interests. Only two significant similarities existed in their historical experiences, namely colonisation and the threat of communism. These contributed greatly in shaping and moulding their world views, thereby influencing their foreign policy and development of foreign relations. 
Their relations began to show signs of remarkable progress in early 1970s, under the Tun Abdul Razak administration. It became clear that the basic underlying factor for a successful economic relation was the complementarity in their natural resources endowments and industrial structures. While Malaysia was endowed with natural resources such as oil, gas, rubber, palm oil and timber, South Korea had to import almost all of its raw material requirements. To make up for the lack of natural resources, it invested heavily in education and training to fulfill its industrialization process and technological advancement. Moreover, rising protectionism in Western industrialized countries also led both the countries to diversify investments to expand into non-traditional markets. These factors formed the basis of bilateral relations during this period. Nevertheless, Malaysia-South Korea economic relationship during this period is found to be moderate and not significantly different than it during the 1960s. Importantly, it was during the period of Tun Hussein Onn that a foundation for South Korean investment in Malaysian manufacturing became prominent. He was particularly supportive of participation of South Korean joint ventures in Malaysian development projects. This was the background against which South Korean participation in Malaysian projects took off remarkably in the subsequent decades under Dr. Mahathir Mohamad, the next prime minister of Malaysia.

\section{References}

Anand, S., Inequality and Poverty in Malaysia: Measurement and Decomposition, Oxford University Press, New York, 1983.

Arroyo, D., The Political Economy of Successful Reform: Asian Stratagems, Stanford, Centre for International Development, California, 2008.

First Malaysia Plan, 1966-1970, Government Press, Kuala Lumpur, 1965.

"Closer Ties our Aim, Says Envoy", New Straits Times, 1 October 1978.

Daño, E. C. and E.D. Samonte, Public Sector Intervention in the Rice Industry in Malaysia, Southeast Asia Regional Initiatives for Community Empowerment (SEARICE), Quezon City, 2005.

Dewan Rakyat (Lower House) Report (19 July 1973), Rang Undang-Undang Majlis Amanah Rakyat (Pindaan) (Majlis Amanah Rakyat Bill) (Amended), Penyata Dewan Rakyat (Hansard), Kuala Lumpur, p. 2548.

Govindasamy, G., 'Malaysia-Korea: 50 Year Relationship', in Geetha Govindasamy, Park Chang Kyoo and Tan Soo Kee (eds), Korean Affairs: A Contemporary View, Department of East Asian Studies, University of Malaya, 2010.

Hindley, D., "Indonesia's Confrontation with Malaysia: A Search for Motives", Asian Survey, Vol. 4, No. 6, 1964, pp. 904-913.

Ishak Shari, "Economic Growth and Income Inequality in Malaysia, 1971-95", Journal of the Asia Pacific Economy, Vol. 5, No. 1-2, 2000, pp. 112-124.

Jain D. and S. Shubha Chacko, "Walking Together: The Journey of the Non-Aligned

"Koreans Fly in to See Progress", New Straits Times, 27 October 1962.

Joint Communique between The Honourable Dato' Hussein Bin Onn Prime Minister of Malaysia and His Excellency Choi Kyu Hah Prime Minister of the Republic of Korea, File 2000/0015899, National Archives of Malaysia, p. 2

Kamal B. Sali, and Mei Ling Young, Structural Adjustment, Employment Policy and Unemployment in Malaysia, Malaysian Institute of Economic Research, Kuala Lumpur, 1988. 
Kanapathy, V., "Industrial Restructuring in Malaysia," in Chia Siow Yue, Donna Vandenbrink and Seiichi Masuyama, (eds), Industrial Restructuring in East Asia: Towards the 21st Century, Institute of Southeast Asian Studies, Singapore, 2001.

"Korean Firm Wins Bridge Contract", New Straits Times, 5 February 1974.

Lee Kyung Chan, 'South Korea-Malaysia Relations', Master's Dissertation. Department of Southeast Asian Studies, Faculty of Arts and Social Sciences, University of Malaya, Kuala Lumpur, 1995.

"Malaysia's Development Plans and Policies (1956-Present),"

http://www.perdana.org.my/pms-of-malaysia/visual-timelines/malaysia-s-development-planspolicies.

"Malaysia-Republic of Korea Diplomatic Relations 1960-2010" (unpublished manuscript), Arkib Negara Malaysia, Kuala Lumpur.

"Malaysia-Korea Economic Relations: Trends and Developments," http://cefia.aks.ac.kr:84/index.php?title=Malaysiakorea_Economic_Relations:_Trends_and_ Developments.

Mid-Term Review of the Third Malaysia Plan, 1976-1980, Government Press, Kuala Lumpur, 1979, p. 78.

Movement and the Women's Movement", Development in Practice, Vol. 19, No. 7, 2009, pp. 895-905.

Nena, V., Area Handbook for Malaysia: No. 3, Washington, D.C: American University Foreign Area Studies, 1977.

Pathmanathan, M., Readings in Malaysia Foreign Policy, Kuala Lumpur: University of Malaya, 1979.

Pollard, K., "ASA and ASEAN, 1961-1967: Southeast Asian Regionalism”, Asian Survey, Vol. 10, No. 3, 1970, pp. 244-255.

"Pursuing Peace, Stability and Work Together for Development, Message from Mr. Sanggin Chyun, Korea's Ambassador to Malaysia”, New Straits Times, 2 October 1977.

Rasiah, R. and Ishak Shari, "Market, Government and Malaysia's New Economic Policy", Cambridge Journal of Economics, Vol. 25, No. 1, 2001, pp. 57-78.

Report on the official visit of YAB Deputy Prime Minister, Dato Seri Dr. Mahathir bin Mohamad to the Republic of Korea from the 5th to the 11th October 1980. File No. 1987/0015734, National Archives of Malaysia, p. 4.

Rethel, L., "Financialisation and the Malaysian Political Economy," Globalizations, Vol. 7, No. 4, 2010, pp. 489-506.

Robertson, J., "Ibrahim bin Ismail", Special Forces Roll of Honour, 2013, http://www.specialforcesroh.com/showthread.php?40621.

"Rural Move Praised by Koreans", New Straits Times, 26 July 1961.

Santhananaban, M., 'Malaysia's First Ambassador', in Fauziah Mohamad Taib, Eds, Number One Wisma Putra, Kuala Lumpur: Institute of Diplomacy and Foreign Affairs, 2006.

Saravanamuttu, J., "ASEAN in Malaysian Foreign Policy Discourse and Practice, 19671997”, Asian Journal of Political Science, Vol. 5, No. 1, 1997, pp. 35-51.

Saravanamuttu, J., Malaysia's Foreign Policy: The First Fifty Years: Alignment, Neutralism, Islamism, Singapore: Institute of Southeast Asian Studies, 2010.

"Seoul asked to send engineers for Malaysian Plan", New Straits Times, 28 April 1977.

Sharpe, S., "An ASEAN Way to Security Cooperation in Southeast Asia?," The Pacific Review, Vol. 16, No. 2, 2003, pp. 231-250. 
Skvortsov, L., The Ideology and Tactics of Anti-Communism (Myths and Reality), Moscow: Progress Publishers, 1969.

Statistics Report on Malaysia's Trade with the Republic of Korea, Department of Statistics, National Archives of Malaysia.

Singh, D., ASEAN and Korea: Emerging Issues in Trade and Investment Relations, Singapore: Institute of Southeast Asian Studies, 1995.

Singh, D., and R.Y. Siregar, ASEAN and Korea: Trends in Economic and Labour Relations, Singapore: Institute of Southeast Asian Studies, 1997.

Speech by Tun Hussein On, Rang Undang-Undang Perbekalan (Supply Bill), Penyata Dewan Rakyat (Hansard), 12 November 1974, pp. 498-524.

Sundaram, J.K., The New Economic Policy and Interethnic Relations in Malaysia, United Nations Research Institute for Social Development (UNRISD), Geneva, 2004.

Sukirno, S., "Growth and Transformation of the Malaysian Economy", 2004, www.ekonomikerakyatan.ugm.ac.id.

Third Malaysian Plan, 1976-1980, Government Press, Kuala Lumpur, 1976, p. 252.

Tiong An Chua, "Transport in Malaysia," Transport Reviews, Vol. 3, No. 3, 1983, pp. 207235.

"Transition to a Democracy and Transformation into an Economic Powerhouse", www.korea.net.

Turnbull, C.M., A History of Modern Singapore, 1819-2005, Singapore: National University of Singapore (NUS) Press, 2009.

Yahaya Ibrahim and Abdul Rasid Abdul Razzaq, "Homestay Program and Rural Community Development in Malaysia," Journal of Ritsumeikan Social Sciences and Humanities, Vol. 2, No, 3, 2010, pp. 7-24.

Zakaria Haji Ahmad, "Malaysia in 1980: A Year of Political Consolidation and Economic Development", Southeast Asian Affairs, 1981, pp. 201-216. 